\title{
TEOLOGI PAULUS TENTANG KARUNIA-KARUNIA ROH DAN IMPLIKASINYA BAGI PROBLEMATIKA PNEUMATOLOGIS GEREJA MASA KINI
}

\author{
Hotman Parulian Simanjuntak
}

\begin{abstract}
PENDAHULUAN
Di sepanjang sejarah perkembangan Gereja yang merupakan sejarah perkembangan teologi hingga pada era postmodern ini, para teolog telah banyak melakukan aktivitas atau upaya menafsirkan, merumuskan, mengajarkan dan memberitakan firman Allah (berteologi). ${ }^{1}$ Meskipun aktivitas atau upaya tersebut belum menghasilkan rumusan doktrin teologi yang signifikan dan berlaku bagi semua kalangan Gereja. ${ }^{2}$ Salah satunya adalah doktrin Pneumatologi yang kembali hangat dibicarakan dan dimonopoli oleh sekelompok Gereja tertentu, sehingga menjadi topik utama yang dibahas oleh hampir seluruh Gereja di dunia ini, termasuk Gerejagereja di Indonesia. ${ }^{3}$ Misalnya, di kalangan Gereja-gereja Injili, terdapat banyak pandangan yang bukan hanya berbeda dan bertentangan dengan bermuara pada dua kubu polarisasi, yakni kubu neo-Pentakosta dan nonPentakosta. ${ }^{4}$ Inilah isu Pneumatologis yang sangat menonjol baik yang pro dan kontra yaitu isu doktrin karunia-karunia Roh yang mengarah kepada perpecahan jemaat. $^{5}$

Karunia-karunia Roh merupakan topik diskusi teologi yang diperdebatkan, antara aliran yang memiliki pandangan bahwa karuniakarunia Roh adalah tanda bukti yang menyertai babtisan Roh Kudus yang harus dimiliki oleh semua orang percaya, dengan aliran yang memiliki pandangan bahwa karunia-karunia merupakan salah satu pemberian Tuhan kepada orang percaya. ${ }^{6}$ Hal ini dimulai dari inteprestasi terhadap karunia-

${ }^{1}$ Lotnatigor Sihombing, Persfektif Teologi Injili Dalam Panggilan Membangun (Batu: Sekolah Tinggi Theologia "I-3," 1995), 4

${ }^{2}$ Ibid.

${ }^{3}$ Stevri I. Lumintang, Keunikan Thelogia Kristen Di Tengah Kepalsuan (Batu: Departemen Multimedia Bidang Literatur, 2009), 248-249

${ }^{4}$ Ibid.

${ }^{5}$ K.S. Lotourette, A History of Christianity. Chapter 2 (New York: Harper \& Row, 1975), 725

${ }^{6}$ D. Bridge \& D. Phypers, Karunia-Karunia Roh Dan Jemaat (Bandung: Kalam Hidup, 1993), 27
\end{abstract}


karunia Roh dan pengalaman rohani oleh orang percaya sejak dulu hingga saat ini. Artinya perbedaan penafsiran dan pengalaman rohani terhadap karunia-karunia Roh Kudus kenyataannya tidak pernah selesai diperdebatkan dikalangan orang-orang percaya, inilah yang disebut problematika, meskipun para teolog Kristen berupaya untuk menyelesaikan masalah ini dengan cara mengkaji lebih dalam dan mendisuksikan bersama, namun dari upaya-upaya ini belum menunjukkan hasil yang signifikan bagi orang percaya sampai hari ini dan masih tetap menjadi problematika. Tendesi orang Kristen memahami karunia-karunia Roh Kudus hanya sebagai karunia yang dibutuhkan untuk menolong dan melengkapi hidup orang percaya. ${ }^{8}$ Perdebatan terjadi antara aliran yang memiliki pandangan dan mengatakan bahwa karunia-karunia Roh masih dilimpahkan oleh Tuhan kepada orang percaya pada masa kini, dengan aliran yang memiliki pandangan bahwa karunia-karunia Roh telah berhenti pada zaman Rasuli, yakni ketika PB lengkap ditulis. ${ }^{9}$ Pada akhirnya banyak orang percaya dipengaruhi pandangan yang terakhir, bahwa orang percaya masa kini tidak lagi menerima karunia-karunia Roh sebagai salah satu karya Allah Tritunggal, sehingga pemahamannya terhadap semua karunia Roh menjadi lain daripada yang sebenarnya dimaksudkan dalam Akitab itu sendiri.

Permasalahan berikutnya juga terjadi dalam sejarah perkembangan teologi, ditemukan adanya gerakan-gerakan rohani yang terus-menerus berkembang, yakni pelayanan karunia karunia Roh Kudus menjadi dasar atau norma untuk menilai dan mengukur kerohanian seseorang. Dengan kata lain, karunia-karunia Roh Kudus menjadi tolak ukur mengenai dipenuhinya seseorang dengan Roh Kudus, bahkan dipakai sebagai dasar keselamatan seseorang. ${ }^{10}$ Ironisnya ada Gereja yang hanya menekankan pengalaman rohani disertai dengan karunia-karunia Rohani saja dalam kehidupan kekristenannya sebagai bukti bahwa ia sungguh-sungguh rohani dan dipenuhi oleh Roh Kudus, serta memiliki kepastian keselamatan. Bahkan tidak jarang orang percaya atau jemaat menghakimi hamba Tuhan atau jemat yang tidak nampak karunia-karunia rohaninya, dengan perkataan-perkataan yang menjatuhkan iman hamba Tuhan atau jemaat,

\footnotetext{
${ }^{8}$ Stanley M. Burgess, Kebutuhan Gereja Saat Ini (Malang: Gandum Mas, 2011), 339

${ }^{9}$ Ibid., 28 1979), 24

${ }^{10}$ Gorden Lindsay, Bagaimana Menerima Babtisan Roh Kudus (Jakarta: Imanuel,
}

${ }^{7}$ H. Berkhof \& L.H. Enklaar, Sejarah Gereja (Jakarta: Badan Penerbit Kristen, 1976), 34 
sehingga hal ini dapat memecahkan kesatuan serta persatuan sesama orang percaya. ${ }^{11}$

Rasul Paulus dalam tulisan-tulisannya secara eksplisit telah banyak memberikan way out secara theologis sebagai solusi terhadap semua permasalahan Pneumatologi yang terjadi di Gereja masa kini. Dari fakta realita problematika karunia-karunia Roh di atas, menstimulir penulis untuk mengkaji dan menganalisa lebih lanjut dan lebih dalam melalui studi theologis secara khusus tentang karunia-karunia Roh dalam konstruksi theologia Rasul Paulus, dimana dalam tulisan Paulus yang mengajarkan tentang konsep, dogma dan prinsip karunia-karunia Roh Kudus secara Alkitabiah. Oleh sebab itu, penulis bermaksud untuk mengangkat hal ini dalam sebuah jurnal "Missio Ecclesio" dengan judul: "Theologia Paulus tentang Karunia-Karunia Roh dan Implikasinya Bagi Problematika Pneumatologis di Gereja Pada Masa Kini.”

\section{KAJIAN BIBLIKA}

Dalam bagian ini penulis akan menguraikan mengenai theologia Paulus secara esensial tentang pengertian karunia-Karunia Roh, maksud karunia Roh, tujuan, asal-mula, banyaknya dan tetap tidaknya karuniakarunia Roh.

\section{Pengertian Karunia-Karunia Roh Menurut Paulus}

Istilah karunia dalam bahasa Yunani ca, risma (kharisma) akar katanya adalah ca, rij (kharis) yang artinya anugerah. Hubungan erat antara dua istilah ini ditekankan oleh Paulus dalam suratnya kepada jemaat di Roma, bahwa: "Demikianlah kita mempunyai karunia (kharisma) yang berlain-lainan menurut kasih karunia yang dianugerahkan kepada kita: Jika karunia itu adalah untuk bernubuat baiklah kita melakukannya sesuai dengan iman kita" (Rm.12:6). Frasa kasih karunia dalam bahasa Yunani ca, rin (kharin) adalah sikap Tuhan terhadap kita, bahwa Dia yang memberi pengampunan kepada manusia, yaitu kepada yang percaya kepada darah Tuhan Yesus. Istilah karunia juga dapat dipakai dengan arti anugerah seperti yang dijelaskan oleh Paulus (Rm 6:23, bnd. 5:15-16) bahwa: “... tetapi karunia (kharisma) Allah ialah hidup yang kekal dalam Kristus

\footnotetext{
${ }^{11}$ Ibid
} 
Yesus, Tuhan kita." Paulus juga mengatakan: "Sebab Allah tidak menyesali kasih karunia (kharisma) dan panggilanNya" (Rm 11:29). Konteks dari ayat terakhir ini tidak berbicara mengenai karunia-karunia tertentu, tetapi panggilan dan kasih karunia yang diberikan kepada bangsa Israel supaya mereka diselamatkan. Karunia merupakan hasil dari anugerah, artinya bahwa karunia tidak bisa dilihat terpisah dari perbuatan dan karya Allah. ${ }^{12}$ Jadi, apa yang disebut dengan karunia adalah karya Allah lewat seseorang dan bukan kemampuan yang dimiliki dan dikuasai sendiri. Karunia dapat disebut juga karya ajaib dan tidak dapat dipisahkan dari pelayanan.

\section{Maksud Karunia-Karunia Roh}

Rasul Paulus menuliskan suratnya kepada jemaat di Korintus mengenai maksud karunia-karunia Roh. Dalam 1Korintus 12:4-6, Paulus menjelaskan bahwa: "Ada rupa-rupa karunia tetapi satu Roh, dan ada ruparupa pelayanan tetapi satu Tuhan, dan ada berbagai-bagai perbuatan ajaib, tetapi Allah adalah satu yang mengerjakan semuanya dalam semua orang." Dalam bagian firman Tuhan ini kita bertemu dengan karya Allah Tritunggal. Tidak ada karunia yang tidak diberikan untuk pelayanan dan tidak ada karunia yang kuasanya tidak berasal dari Allah. Paulus memakai tiga kata ucapan yang hampir sama untuk menjelaskan satu hal hal yang sama, yaitu: karunia, carisma, twn (kharismaton), pelayanan, diakoniw/n (diakonion) dan karya ajaib, evnerghma, twn (energematon). ${ }^{13}$ Paulus juga menjelaskan bahwa karunia tertentu diberikan "untuk melengkapi orang-orang kudus bagi pekerjaan pelayanan" (Ef 4:12). Kalimat ini berbicara mengenai karunia-karunia yang diberikan dengan tujuan pelayanan. Masing-masing karunia dan masing-masing perbuatan yang ajaib dilakukan oleh Allah. Hal ini nampak dalam kesimpulan Paulus (1Kor 12:5), bahwa: "tetapi Allah adalah satu yang mengerjakan semuanya dalam semua orang." Kalimat ini sangat jelas sekali mengajarkan bahwa karunia-karunia Roh bukan karya manusia, tetapi karya Allah secara terusmenerus. Dengan demikian, Allah yang bekerja dan Roh Kudus terlibat dalam pekerjaan ini, seperti yang dijelaskan oleh Paulus (1Kor 12:11)

12 T.G.R. Boeker, Apa Kata Alkitab Tentang Roh Kudus (Malang: Institut Injil Indonesia, 1991), 42

${ }^{13}$ View from one angle they appar as charismata, form another as misnitrations, and from a third as energies. Maksudnya adalah, jika dilihat dari satu arah ternyata sebagai karunia, dari arah yang lain sebagai pelayanan, dan dari arah ketiga sebagai kuasa; R.C.H. Lenski, The Interpretations of 1 and 2Chorinthians (Minnesota: Augsburg, 1963), 495 
bahwa: "Tetapi semuanya ini dikerjakan oleh Roh yang satu dan yang sama, yang memberikan karunia kepada tiap-tiap orang secara khusus, seperti yang dikehendaki-Nya."14

\section{Tujuan Karunia-Karunia Roh}

Dalam Roma 12:4-5 Paulus menggambarkan jemaat sebagai tubuh Kristus dan jemaat adalah anggota tubuh itu. Setelah itu barulah ia mengemukakan karunia-karunia yang berlainan dan yang dimiliki oleh orang-orang Kristen ( $\mathrm{Rm}$ 12:6-8). Paulus dalam pembahasan yang lebih panjang lebar tentang karunia-karunia Roh dalam 1Korintus 12:27-28: "Kamu semua adalah tubuh Kristus dan kamu masing-masing adalah anggotanya. Dan Allah telah menetapkan beberapa orang dalam jemaat, pertama sebagai rasul, kedua sebagai nabi ...” Demikian juga dalam Efesus 4:1-8, Paulus menyatakan bahwa justru karena orang-orang Kristen adalah anggota-anggota satu tubuh, maka kasih karunia telah dianugerahkan kepada mereka masing-masing menurut ukuran pemberian Kristus. ${ }^{15}$ Pada ketiga bagian teks ini dijelaskan bahwa karunia-karunia Roh mempunyai dua tujuan vital dalam kehidupan jemaat.

Pertama, karunia-karunia roh memperkuat persekutuan jemaat. Kehendak Allah bagi jemaat ialah, "supaya jangan terjadi perpecahan dalam tubuh, tetapi supaya angota-anggota yang berbeda itu saling memperhatikan. Karena itu jika satu anggota menderita, maka semua anggota turut menderita; jika satu anggota dihormati, maka semua anggota tubuh turut bersukacita" (1Kor 12:25-26). Berbagai karunia dibagikan di antara anggota-anggota jemaat supaya tujuan itu dapat dicapai (1Kor 12:2730). Dalam kerinduan mereka untuk memperoleh karunia-karunia Roh dan untuk menggunakan karunia-karunia itu, orang-orang Kristen "hendaknya berusaha mempergunakannya untuk membangun jemaat" (1Kor 14:12). Demikian pula dalam Efesus 4:12,16, Paulus mengemukakan bahwa karunia-karunia Kristus adalah "bagi pembangunan tubuh Kristus," dan apabila orang-orang Kristen menggunakan karunia-karuia itu dengan benar, maka jemaat "menerima pertumbuhannya dan membangun dirinya dalam kasih." 16

\footnotetext{
${ }^{14}$ Ibid.

${ }^{15}$ Donald Bridge \& David Phypers, Karunia-Karunia Roh dan Jemaat (Bandung: Penerbit Kalam Hidup, 1973), 17

${ }^{16}$ Ibid., 18
} 
Kedua, selain menguatkan persekutuan jemaat, karunia-karunia Roh juga dimaksudkan untuk memperluas kesaksian dan pelayanan jemaat. Di dalam ayat-ayat yang memang sukar untuk dipahami, yaitu 1Korintus 14:20-25, rupanya Paulus mengemukakan bahwa manifestasi karuniakarunia Roh yang dapat dipahami, orang akan menyadarkan orang sesat akan dosanya, "sehingga ia akan sujud menyembah Allah dan mengaku, sungguh, Allah ada di tengah-tengah kamu" (1Kor 14:25). Bahkan lebih jelas dalam Efesus 4:11-12, Paulus mengatakan bahwa karunia-karunia itu untuk memperlengkapi orang-orang kudus bagi perkerjaan pelayanan. Yang juga penting dalam ayat ini ialah bahwa Paulus secara khusus mengakui jabatan Rasul dan pemberita Injil. ${ }^{17}$

\section{Sifat Karunia-Karunia Roh}

Rasul Paulus secara mendalam membahas sifat karunia-karunia Roh dengan menggunakan beberapa kata Yunani untuk menggambarkan karunia-karunia roh, yakni: kata pneumatikoi (pneumatikoi) "perkaraperkara rohani." Kata itu berasal dari kata pneuma (pneuma), dan pengunaan kata pneumatikoi (pneumatikoi) menunjukkan bahwa karunia-karunia itu adalah milik Roh Kudus dan digerakkan oleh Roh Kudus atau semua karunia itu "dikerjakan oleh Roh yang satu dan yang sama" (1Kor 12:11). Karunia-karunia itu bersifat supranatural, karena digerakkan Allah. ${ }^{18}$

Dalam menggambarkan karunia-karunia Roh, Paulus beralih dari kata pneumatikoi (pneumatikoi) dalam ayat 1 ke kata ca, rismata (kharismata) dalam Roma 12:4. Walaupun sering diterjemahkan menjadi karunia-karunia saja, kata kharismata sebenarnya berarti karunia-karunia yang diberikan karena kemurahan hati pemberinya. Penggunaan kata ini menekankan kenyataan bahwa karunia-karunia itu berasal dari kasih dan rahmat Allah yang melimpah-limpah. Kata ketiga yang digunakan oleh Paulus dalam 1Korintus 12:5 untuk menggambarkan karunia-karunia Roh ialah kata diakonia (diakonia) artinya pelayanan, digunakan dalam PB untuk menggambarkan jabatan dan pekerjaan seorang diaken atau pelayan dalam jemaat. Hal ini mengindikasikan bahwa karunia-karunia itu hendaknya dipergunakan bagi kepentingan bersama. Orang Kristen yang mempergunakan karunia-karunia Roh hendaknya meneladani Juruselamat

\footnotetext{
${ }^{17}$ Ibid.

${ }^{18}$ Bridge \& Phypers, Karunia-Karunia..., 20, 21
} 
dalam hal kematian-Nya di atas kayu salib. ${ }^{19}$ Paulus juga menggunakan kata energema diterjemahkan menjadi "perbuatan ajaib" untuk menggambarkan karunia-karunia Roh yang berasal dari kata energeo yang dalam bentuk pasifnya berarti didorong atau digerakkan dan di dalam PB selalu dipakai untuk menyatakan suatu prinsip atau kuasa yang sedang bekerja. Hal ini menggambarkan berbagai karunia itu sebagai "berbagaibagai perbuatan ajaib." Apabila karunia-karunia Roh dipergunakan, maka kuasa Allah sedang bekerja di dalam diri orang Kristen bagi kepentingan orang lain. Kata terakhir yang dipakai oleh Paulus untuk menggambarkan sifat karunia-karunia Roh ialah phanerosis. Kata itu berasal dari kata kerja phaneroein yang berarti menjadikan kelihatan, jelas atau diketahui. Karunia-karunia adalah "penyataan Roh."

\title{
Asal Mula Karunia-Karunia Roh
}

Dalam 1Korintus 12 Paulus menghubungkan asal mula dan distribusi karunia-karunia Roh dengan setiap pribadi dari Allah Tritunggal. Paulus menulis "ada rupa-rupa karunia, tetapi satu Roh. Dan ada rupa-rupa pelayanan, tetapi satu Tuhan. Dan ada berbagai-bagai perbuatan ajaib, tetapi Allah adalah satu yang mengerjakan semuanya dalam semua orang." Yang sangat mengesankan ialah cara setiap Pribadi dalam Allah Tritunggal dihubungkan dengan berbagai segi daripada karunia-karunia itu. Dengan demikian, karena kegiatan khusus daripada Roh Kudus ialah membagi-bagikan, maka Paulus berbicara tentang "karunia-karunia-Nya." Karena Yesus datang bukan untuk dilayani, melainkan untuk melayani, maka Paulus berbicara tentang "rupa-rupa pelayanan-Nya." Karena Allah Bapa adalah sumber segala kuasa, maka Paulus berbicara tentang "berbagai-bagai perbuatan ajaib-Nya." ${ }^{20}$ Karena itu, dapat disimpulkan bahwa ada kegiatan yang maha hebat didalam penggunaan karunia-karunia Roh. Pada waktu karunia-karunia itu dipergunakan oleh seseorang anggota tubuh Kristus, maka Allah Tritunggal bekerja di dalam satu pribadi bagi kepentingan dan kebaikan orang-orang lain. Inilah asal mula atau sumber utama dari banyaknya karunia Roh.

\section{Banyaknya Karunia-Karunia Roh}

\author{
${ }^{19}$ Ibid., 22 \\ ${ }^{20}$ Bridge \& Phypers, Karunia-Karunia Roh..., 24
}


Dalam 1Korintus 12:8-19 memang hanya sembilan karunia yang dikemukakan, tetapi Paulus memberikan serangkaian karunia yang lain di dalam pasal yang sama. Demikian juga dalam Roma 12 dan Efesus 4 dan ayat-ayat yang lainpun Paulus menyinggung beberapa karunia lain. Dalam Roma 12 tercantum karunia-karunia untuk bernubuat, untuk melayani, untuk mengajar, untuk menasehati, untuk membagi-bagkan sesuatu, untuk memberi pimpinan dan untuk menunjukkan kemurahan. Dalam 1Korintus 12 tercantum karunia-karunia untuk berkata-kata dengan hikmat, untuk berkata-kata dengan pengetahuan, karunia iman, karunia untuk menyembuhkan, untuk mengadakan mujizat, untuk bernubuat, untuk membeda-bedakan roh, untuk berkata-kata dengan bahasa Roh, untuk menafsirkan bahasa Roh, karunia untuk menjadi Rasul dan pengajar, karunia untuk melayani dan karunia untuk memimpin. Efesus 4 mengemukakan jabatan dan bukan pekerjaan, yaitu rasul-rasul, nabi-nabi, pemberita-pemberita Injil, gembala-gembala dan pengajar-pengajar. Selain itu, karunia membujang secara sukarela (1Kor 7), kemiskinan dan kesahidan secara sukarela (1Kor 13:3) adalah karunia-karunia dalam arti yang sama seperti karunia-karunia yang lain dan harus dimasukkan ke dalam golongan karunia. ${ }^{21}$ Apabila suatu jemaat atau kelompok Kristen memusatkan perhatian hanya pada beberapa karunia saja dan melupakan adanya berbagai karunia lain yang dikemukakan dalam PB, maka mereka hanya setengah-setengah dan tidak lengkap; mereka akan kehilangan berkat, baik di dalam dan di luar persekutuan.

\section{Tetap Tidaknya Karunia-Karunia Roh}

Beberapa karunia Roh jelas lebih supernatural dan lebih ajaib daripada yang lainnya, dan dalam sejarah jemaat karunia-karunia itu kadang-kadang tidak dipergunakan lagi untuk jangka waktu yang lama. Paulus memang mengatakan bahwa "nubuat akan berakhir, bahasa Roh akan berhenti; pengetahuan akan lenyap" (1Kor 13:8), dan ayat ini sering dikutip orang untuk menekankan bahwa karunia-karunia yang dramatis hanya bersifat sementara. Tetapi kita harus memperhatikan juga konteksnya. Paulus sedang berbicara tentang masa depan, yaitu pada waktu "yang sempurna tiba; pada waktu itulah yang tidak sempurna itu akan lenyap (1Kor 13:10). Demikian juga Paulus mengatakan bahwa "Sekarang kita melihat secara samar-samar, tetapi nanti kita akan melihat muka dengan muka. Sekarang kita hanya mengenal dengan tidak sempurna, tetapi

${ }^{21}$ Bridge \& Phypers, Karunia-Karunia Roh..., 25 
nanti kita akan mengenal dengan sempurna" (1Kor 13:12). Dari pernyataan ini sangat jelas bahwa Paulus sedang melihat ke masa depan pada waktu bukan saja karunia-karunia Roh yang menakjubkan, tetapi segala sesuatu yang mencakup kehidupan manusia sehari-hari akan lenyap pada waktu Allah menggenapkan janji-Nya dalam kemuliaan-Nya. ${ }^{22}$

\section{Pandangan Rasul Paulus Tentang Karunia-Karunia Roh}

Dalam semua tulisan Rasul Paulus mengenai karunia-karunia Roh terdapat suatu hakikat yang benar untuk dapat memahami dengan benar semua karunia Roh yang diberikan Allah kepada umat-Nya, yaitu:

\section{Karunia Sebagai Rasul}

Dalam tulisan Paulus, istilah rasul dipakai mengenai Epafroditus dan beberapa orang lain. Mereka disebut sebagai "utusan Gereja-gereja," avpo, stoloi evkklhsiw/n (apostoloi ekklesion) yang juga terdapat dalam 2Korintus 8:23, dan utusan kamu, u`mw/n de. avpo, stolon (humon de apostolon) terdapat dalam Filipi 2:25. Istilah utusan dalam konteks ini sama dengan istilah rasul, avpo, stoloi (apostoloi). Dua ayat ini berbicara tentang "utusan-utusan dari jemaat-jemaat," bukan "Rasul Kristus Yesus oleh kehendak Allah" (Ef 1:1). Dalan surat Korintus mereka yang disebut "utusan-utusan" adalah beberapa orang yang dipilih oleh jemaat-jemaat di Asia untuk mengkuti Paulus dan Titus, sewaktu mereka membawa suatu persembahan dari jemaat-jemaat yang baru beridiri kepada jemaat induk di Yerusalem (2Kor 8:19). Sebetulnya mereka diikutsertakan sebagai saksi (2Kor 8:20). Hal ini didukung argumentasi Donald Guthrie sebagai berikut:

Apostolic ministry was distinguished from all other ministry; Apostolic ministry has not localized but universal; The apostles was in no sense appointed by the church, but rather were foundation to it (cf. Eph.2:20); Their task has not only to lay foundation, but also to contribute to the upbilding of the church. ${ }^{23}$

\footnotetext{
${ }^{22}$ Bridge \& Phypers, Karunia-Karunia Roh..., 29, 30

${ }^{23}$ Donald Guthrie, Tafsiran Aliktab Masa Kini. Jilid III (Jakarta: BPK Gunung Mulia, 1982), 82
} 
Dengan demikian dapat disimpulkan bahwa, pelayanan kerasulan dibedakan dari pelayanan lain, wewenang para Rasul tidak hanya berpengaruh pada suatu daerah setempat tetapi bagi semua orang, para Rasul tidak diangkat oleh jemaat, malah merekalah pendiri jemaat (bnd. Ef 7:20) dan tugas mereka bukan hanya meletakkan dasar, tetapi juga berperan untuk menegakkan jemaat. Oleh sebab itu, para rasul adalah dasar Gereja yang terutama, karena pengajaran mereka yang ada di dalam Perjanjian Baru menjadi dasar dan patokan bagi Gereja universal dalam segala zaman.

\section{Karunia Sebagai Nabi}

Dalam tulisan Paulus, dijelaskan bahwa istilah nabi mempunyai arti ganda, yaitu nabi PL (Rm 1:22; 3:21) dan nabi PB (1Kor 12:28). Dalam Efesus 3:5 artinya mungkin "nabi PB." Hal ini nampak karena dikatakan bahwa rahasia ini "pada angkatan dahulu tidak diberitakan kepada anakanak manusia," berarti ditutup sampai PB. Paulus di sini memakai frasa dinyatakan dalam Roh, avpekalu, fqh evn Pneu, mati (apekaluphte en Pneumati) tentang pengalaman para rasul, berarti mereka mendapat wahyu dari Allah sebagainana seorang pelihat (ro'eh). Boleh dikatakan juga bahwa, arti istilah rasul dan istilah nabi tidak terlalu berbeda. Dua-duanya adalah utusan Allah.

Dalam surat Efesus para nabi dan rasul dilihat sebagai dasar jemaat (Ef 2:20) yang sewaktu-waktu disatukan, seperti yang dijelaskan Paulus dalam Efesus 3:5, di mana dalam konteks ini istilah Rasul (apostolois) memakai kata sandang tertentu, tetapi istilah nabi (prophetais) tidak memakai kata sandang tertentu, berarti dua kelompok ini disatukan oleh istilah dan, kai (kai). Menurut Robertson: sometimes groups more or less distinct are treated as one for the purpose in hand, and hence use only one article. ${ }^{24} \mathrm{Jadi}$, Paulus dan duabelas rasul diberi nama nabi dalam teks ini.

Dalam struktur teks Efesus 2:20 bahwa frasa $t w / n$ avposto, lwn kai. profhtw/n (ton apostolon kai propheton) sama dengan struktur teks Efesus 3:5. ${ }^{25}$ Para rasul dan para nabi adalah satu kelompok, yaitu rasul-rasul yang mempunyai karunia nabi. Sedangkan dalam surat Ef.4:11, nabi dan rasul tidak satu kelompok, tetapi Paulus berbicara mengenai dua kelompok yang berbeda, seperti penginjil, pengajar

\footnotetext{
${ }^{24}$ A.T. Robertson, A Grammar of the Greek New Testament in the Light of Historical Research (Tennessee: Broadman, 1994), 787 1994), 51

${ }^{25}$ E. Waaler, Exposition of the Letter to the Ephesians (Unplublished Manuscript,
} 
dan gembala merupakan kelompok yang terpisah. ${ }^{26}$ Meskipun demikian kesimpulan penulis adalah bahwa Paulus dalam surat Efesus pasal dua dan tiga berbicara mengenai rasul dan nabi dalam arti satu kelompok, yaitu rasul yang memiliki karunia nubuat. ${ }^{27}$

\section{Karunia Bernubuat}

Pembahasan tentang karunia nabi sebagai salah satu karunia tidak dapat lepas dari istilah nubuat. Paulus membahas tentang tugas seorang nabi (1Kor 14:29), profh/tai (prophetai), Paulus juga berbicara mengenai nabi yang menerima wahyu dari Tuhan. Tuhan mewahyukan sesuatu kepada sesuatu kepada mereka (1Kor 14:30) avpokalufqh/ (apokaluphte), yang kemudian mereka sampaikan (1Kor 14:31) profhteu, ein (propheteuein). Seluruh fenomena ini diberi nama propheteia (1Kor 14:22) artinya aktivitas seorang nabi. Sebenanya harus diperhatikan bahwa ada perbedaan antara istilah "menerima wahyu atau nubuat" (apokaluphte) dan istilah bernubuat (propheteuein). Istilah wahyu sering dipakai tentang pengalaman Paulus sendiri, secara khusus wahyu sebagai dasar jabatan Rasul (Rm 18:25; 1Kor 14:8; 2Kor 1:1-7; Gal 1:12, 15, 2:22; Ef 3:3). Tetapl istilah wahyu juga dapat dipakai mengenai orang Kristen secara umum (Ef 1:17; Flp 3:15) dan tentang karunia nubuat secara khusus (1Kor 14:28,30; bnd. 1Kor 14:6). Menurut Ridderboes, Prophecy is a special form of the Spirit given to through the church. For this speaking of the prophets can also be called relevation. ${ }^{28}$ Jadi, dapat dikatakan bahwa, nubuat artinya "suatu pemberian Roh kepada dan melalui jemaat." Oleh karena itu, apa yang dikatakan para nabi dapat disebut nubuat. Meskipun karunia nubuat juga ada di dalam jemaat pertama, tetapi otoritas nubuat dalam jemaat lebih rendah daripada otoritas seorang rasul, seperti yang dijelaskan dalam 1Korintus 14:37-38.

Secara positif Paulus mengarahkan supaya nubuat dipakai sesuai dengan iman dalam bahasa Yunani kata. th.n avnalogi, an th/j pi, stewj (kata ten analogian tes pisteos) Roma 12:6. Maksudnya di sini bukan iman pribadi seseorang, tetapi inti dari iman Kristen. Dengan

${ }^{26}$ tou.j me.n tou.j de. (tous men tois de) dengan arti yang kontras; bnd. Robertson, A Grammar of the..., 1152

${ }^{27}$ The apostles are also prophets in the New Testament sense. Graham Huston, Prophecy Now, (U.K.: Inter-Varsity, n.d.), 80

Eerdmans, 1990), 451

${ }^{28}$ H. Ridderbos, Paul, An Outline of His Theology (Grand Rapids, Michigan: 
demikian, iman yang dimaksud oleh Paulus adalah iman sesuai dengan isinya, atau secara umum doktrin Kristen. Karena nubuat yang dibuat oleh seorang rasul atau nabi mempunyai otoritas yang jauh lebih tinggi daripada nubuat yang dibuat oleh seseorang yang berkarunia nubuat. Hal ini tidak terlepas dari karunia mengajar.

\section{Karunia Mengajar}

Dalam surat Paulus istilah pengajar tidak berdiri sendiri, tetapi berhubungan dengan istilah penatua, presbuteroj (presbuteros), "Penatua-penatua yang baik pimpinannya patut dihormati dua kali lipat, terutama mereka yang dengan jerih payah berkhotbah dan mengajar" (1Tim 5:17). Tugas yang kedua yang dihubungkan dengan tugas penatua adalah gembala, poimenoj (poimenos). Paulus memanggil penatua-penatua dari Efesus (Kis 20:17). Kepada kelompok ini Paulus mengatakan: "karena kamulah yang ditetapkan Roh Kudus menjadi penilik untuk menggembalakan jemaat Allah" (Kis 20:28). Dalam surat Petrus juga nampak bahwa, para penatua harus menggembalakan umat Tuhan (1Ptr 5:1-4). Demikian juga para pengajar dan gembala dilihat bersama dalam surat Efesus: "maupun gembala-gembala dan pengajar-pengajar" (Ef 4:11). Paulus menyebutkan lima gelar, yaitu: rasul, nabi, penginjil, guru dan gembala. Setiap empat istilah pertama masing-masing didahului oleh artikel tertentu, tetapi yang terakhir tidak tou.j de. ( poime, naj kai. didaska, louj (tous de poimenas kai didaskalous). Dari hal ini, maka dapat disimpukan bahwa, dua kelompok ini dekat dan dilihat sebagai kesatuan dalam konteks ini.

Selanjutnya, dalam tulisan Paulus dijelaskan adanya hubungan antara seorang penilik dan seorang penatua. Dari segi tugas dua-duanya disebut tenaga yang mengajar (1Tim 3:2; Tit 1:9) dan juga sebagai orang yang menjaga jemaat (1Tim 5:17; Tit 1:9). Paulus dalam suratnya kepada Titus, memakai istilah penilik (Tit 1:7) dan penatua (Tit 1:5) tentang orangorang yang sama. Juga dalam konteks ini khotbah Paulus kepada para penatua dari Efesus sangat cocok, karena mereka disebut: "Penatua (Kis 20:17) dan Penilik (Kis 20:28) yang menggembalakan (Kis 20:28)."29 Bahkan dalan surat pastoral Paulus kepada Timotius, terdapat istilah pengajar dilihat dalam konteks pemerintahan jemaat: "mengajar atau

29 "Eph. 4:11 qualifies 'pastors and teachers' more as an activity than as an office, though the office of overseer can wall be aluded to (cf. Phil. 1:1)." Ridderboes, Paul, An Outline..., 455 
memerintah" (1Tim 2:12, terjemahan lama). Sepertinya para pengajar diberi kuasa untuk memerintah di dalam jemaat. Memang seorang guru selalu menggurui muridnya, tetapi kuasa ini kemungkinan besar mempunyai hubungan dengan tugas penatua yang juga memimpin jemaat.

Tugas utama seorang pengajar tentunya untuk membagikan pengetahuan seperti yang dijelaskan oleh Paulus dalam 1Korintus 14:6, bahwa: "jika aku tidak menyampaikan kepadamu penyataan, avpokalu, yei: (apokaluphei) Allah atau pengetahuan, gnw, sei: (gnosei) atau nubuat, profhtei, al (propheteia) atau pengajaran, didach (didakhe)." Dalam hal ini, berarti bahwa pengajaran sama dengan pengetahuan, seperti nubuat sama dengan penyataan. Frasa kata pengetahuan juga muncul di dalam konteks karunia-karunia (1Kor 12:8), dimana dalam konteks yang sama istilah kata hikmat, sofi, aj (sophia) juga muncul, bahkan terlihat juga dalam surat Kolose bahwa, pengajaran juga berisi kata hikmat (Kol 3:16). Dengan demikian, baik kata hikmat maupun pengetahuan adalah isi dari pengajaran.

\section{Karunia Berbahasa Lidah}

Paulus secara eksplisit (1Kor 14:14) menjelaskan bahwa kalau dia berdoa dengan bahasa lidah, maka: rohku, to. pneu/ma, mou (to pneuma mou) yang berdoa. Kalau roh Paulus yang berdoa, maka roh itu bukanlah Roh Kudus. Jelas sekali bahwa Paulus membedakan antara roh manusia dan Roh Kudus: "Roh itu bersaksi bersama-sama dengan roh kita bahwa kita adalah anak-anak Allah" (Rm 8:16) ${ }^{30}$ Paulus juga menekankan bahwa bahasa lidah tidak dimengerti oleh manusia, kecuali mereka diberikan karunia untuk menafsirkan bahasa lidah (bnd. 1Kor 14:28). Menurut Ridderboes bahwa: Bahasa lidah tidak ada hubungannya dengan akal, tetapi keluar dari roh manusia: "rohku yang berdoa tetapi akal budiku tidak turut berdoa" (1Kor 14:14). Dalam bahasa asli dipakai istilah a;karpo,j (akarpos) artinya tanpa buah. Yang dimaksudkan oleh Paulus ialah bahwa, akal budi tidak berbuah dalam hal berbicara dengan bahasa lidah. Dikatakan mengenai akal budi bahwa di dalam bahasa lidah akal tidak berbuah (1Kor 14:14), maka akal budi tidak terlibat di dalamnya. ${ }^{31}$ Jadi, bahasa lidah tidak berasal dari akal budi manusia, tetapi dari roh manusia.

${ }^{30}$ Lenski, Interpretation of Romans ..., 524

31 "It is said of the understanding therefore that with glossolia it is unfruitful (v. 14), that is to say, it is not involved in it;" Ridderboes, Paul, an Outline of..., 465 
Istilah bahasa lidah yang dibicarakan Paulus dalam surat 1Korintus 14:2 adalah doa dan pujian kepada Tuhan: "Siapa yang berkata-kata dengan bahasa roh, tidak berkata-kata kepada manusia, tetapi kepada Allah." Istilah berkata-kata (lalei, lalaei) dilengkapi dengan istilah Allah dalam kasus datif Qew (Theo) kasus datif menjelaskan bahwa, orang yang kepadanya kami berbicara. ${ }^{32}$ Hal ini berarti bahwa bahasa lidah ditujukan bukan kepada manusia melainkan kepada Allah. Istilah berdoa dengan bahasa lidah dan berdoa dengan rohku (1Kor 14:14), sama maknanya dengan "menyanyi dan memuji dengan rohku" (1Kor 14:15), "mengucapkan syukur dengan rohmu" (1Kor 14:16). Maka jelaslah dari konteks ini bahwa apa yang dilakukan adalah doa dan pujian kepada Allah. Dalam jemaat hanya dibutuhkan doa yang dapat diaminkan oleh saudara-saudara seiman: "bagaimanakah orang biasa yang hadir sebagai pendengar dapat mengatakan "amin" atas pengucapan syukurmu?" (1Kor 14:16). Hal ini disebabkan bahwa bahasa lidah selalu harus diterjemahkan, kecuali kalau orang berdoa seorang diri. Bahasa lidah juga harus membangun orang yang berbicara: "hanya boleh berkata-kata kepada dirinya sendiri dan kepada Allah" (1Kor 14:28), "Siapa yang berkata-kata dengan bahasa roh, ia membangun dirinya sendiri" (1Kor 14:28). Persekutuan dengan Allah dalam bentuk ini menolong seseorang dalam kehidupannya dengan Tuhan.

Dalam beberapa golongan Kristen tertentu, bahasa lidah menjadi ukuran terhadap iman dan kerohanian seseorang. Bahasa lidah menjadi tanda mutlak untuk pertobatan atau tanda berkat kedua (second blessing). Tetapi hal ini tidak sesuai dengan Alkitab. Paulus menjelaskan dalam suratnya kepada jemaat di Korintus, seperti berikut: "Adakah mereka semua rasul, atau nabi, atau pengajar? Adakah mereka semua mendapat karunia untuk mengadakan mujizat, atau untuk menyembuhkan, atau untuk berkata-kata dalam bahasa roh, atau untuk menafsirkan bahasa roh?" (1Kor 12:29-30). Pada bagian ini Paulus ingin lebih menekankan bahwa meskipun masing-masing orang diberikan karunia yang berbeda, tetapi kita semua satu dalam Kristus. Sama sekali tidak ada satu ayat Firman Tuhan yang mengatakan bahwa bahasa lidah adalah tanda bagi suatu tingkatan kerohanian ataupun syarat untuk selamat. Karunia bahasa lidah adalah karunia yang terkecil. Paulus dengan tegas menolak segala pikiran bahwa satu anggota tubuh tidak berharga, karena dia tidak memiliki satu karunia tertentu (1Kor 12:12-20).

32 "The pers. To whom for with whom one is speaking." Bauer, A greek English Lexicon of the Greek New Testament and Other Early Christian Literature (Chicago: University of Chicago Press, 1975), 464 


\section{Karunia Iman, Penyembuhan dan Karya Ajaib}

Dalam surat-suratnya, Paulus memiliki tiga karunia yang sering disambung dengan karya ajaib, yaitu iman, pi,stij (pistis), karuniakarunia penyembuhan, cari.smata i.amaton (kharismata iamaton) dan karya ajaib, evnergemata duna.mewn (energemata dunameon). Ketiga istilah ini akan diuraikan oleh penulis dalam pemaparan berikut ini.

\section{Karunia Iman dan Kuasa Allah}

Dalam surat 1Korintus 13 dibicarakan tentang apa yang dapat disebut dengan karunia iman, pistij (pistis). Iman yang dibicarakan dalam ayat ini tidak cukup untuk seseorang selamat, meskipun ada tanda ajaibnya. Apa yang ingin disampaikan oleh rasul Paulus ialah bahwa "tanda ajaib" tidak boleh menjadi ukuran iman. Orang Kristen tidak boleh begitu terkesan oleh keberanian seorang martir atau pengorbanan atau mujizat 'yang besar,' agar jangan tanda semacam itu dijadikan bukti bahwa Allah yang bekerja. Sebenarnya dalam surat 1Korintus 13 "iman yang memindahkan gunung" dinyatakan tidak berguna kalau tidak disertai oleh kasih. Sebaliknya iman yang dicari dan iman yang menjadi contoh terdapat dalam ayat 13: Iman, pengharapan dan kasih. Istilah karunia iman paralel dengan istilah pengharapan yang merupakan istilah eskatologis. Hal ini dapat dihubungkan dengan masalah kekuatiran. Dalam Injil Matius jelas bahwa semua orang Kristen, tanpa terkecuali, tidak perlu kuatir tentang hari esok (Mat 6:25-34). Hal itu dibuat sebagian dari jemaat Tesalonika, dan Paulus cukup tegas menegur mereka (2Tes 3:11-12). Apa yang disampaikan oleh Yesus berlaku bagi orang-orang sederhana. Mereka tidak perlu kuatir akan hasil dari tanahnya, karena Tuhan tahu pergumulan mereka. Jadi, iman sebagai keyakinan akan kemahakuasaan Allah yang membuat mujizat tidak hanya diberikan kepada sebagian orang percaya, tetapi sebagaimana dalam Roma 4:17-20, hal yang sama juga adalah esensi dari perbedaan antara orang percaya sebagai anaknya Abraham dan orang yang tidak percaya. ${ }^{33}$

33 "For the faith as trust in the wonderworking omnipotence of God is not only given to some, but, as appears from Romans 4:17-20, also defines the essence of that 


\section{$\underline{\text { Karunia atau Hasil Anugerah }}$}

Paulus mengatakan bahwa satu karunia dapat dimiliki, namun "kita mempunyai karunia yang berlainan" ( $\mathrm{Rm} 12: 6)$. Istilah mempunyai, e;contej (ekhontes) berbicara tentang sesuatu yang diberikan Allah untuk dimiliki dan dipakai. Hal yang sama nampak juga, ketika Paulus memberikan nasihat kepada Timotius: "Oleh karena itu kuperingatkanan engkau untuk mengobarkan karunia yang ada padamu oleh penumpangan tangan atasmu" (2Tim 1:7). Paulus memakai frasa $\circ$ [ evstin evn soi (ho estin en soi) artinya yang ada didalam kamu, yang berarti karunia itu dilihat sebagai milik Timotius, meskipun sedang tidak (atau kurang) dipakai.

Dua jalur ini dapat disatukan dalam istilah yang berhubungan dengan tiga istilah, yaitu: "karunia, pelayanan dan hasil kuasa" (1Kor 12:46). Karunia yang dimiliki diberikan untuk pelayanan dan berfungsi demi kuasa Tuhan, dan setiap orang memiliki paling tidak satu karunia (1Ptr 4:10). Kedua teks ini berbicara mengenai sesuatu yang diberi kepada setiap, e/kastoj (ekastos) orang (1Kor 12:7; 1Ptr 4:10). Jadi, karunia iman bukan merupakan kepintaran atau keahlian yang dikuasai sendiri oleh orang percaya. Karena pendapat ini dekat dengan masalah synergisme, yakni bahwa keselamatan merupakan hasil kerjasama Allah dan manusia. Oleh sebab itu, "iman bukanlah karya manusia, karena iman merupakan karya Allah di dalam dan bagi orang percaya."

\section{Karunia Penyembuhan dan Karunia Karya Ajaib}

Kedua karunia ini sebagaimana dengan semua karunia yang lain, berhubungan dengan iman. Dan dua karunia ini sifatnya sama, hanya obyeknya yang berbeda. Penyembuhan adalah salah satu macam karya ajaib. Kata penyembuhan memakai istilah i/ama (iama), dan perbuatan ajaib memakai kata e, ne.rgema (energema), kedua kata ini memakai akhiran ma ( $m a$ ). Sama seperti istilah kharisma (anugerah), dua istilah ini menekankan karya Allah dalam karunia ini, yakni bahwa "penyembuhan

which distinguishes every believer as a child of Abraham from unbelievers;" Ridderbos, Paul an Outline if ..., 464 
dan mujizat merupakan hasil dari karya Allah.” Dua istilah tersebut hanya dipakai dalam pasal ini, dan tidak terdapat dalam bagian lain dari PB.

Paulus sesudah mendaftarkan semua karunia, selanjutnya ia berkata: "Tetapi semua ini dikerjakan e [nergei (energei) oleh Roh yang satu dan sama yang membagikan kepada tiap-tiap orang sesuai apa yang dikehendaki-Nya." Dari hal ini, maka nampaklah bahwa Allah yang bekerja dalam dua karunia ajaib ini. Harus ditekankan di sini bahwa masalah sakit penyakit tidak selalu terikat dengan dosa. Juga tidak mungkin untuk mengatakan bahwa orang yang sakit kurang beriman. Hal ini tidak sesuai dengan Firman Tuhan.

\section{Karunia Untuk Membedakan Roh}

Dalam 1Korintus 12:10 Paulus menjelaskan: "karunia untuk membedakan barmacam-macam roh." Untuk menguji para roh adalah merupakan kehendak Roh Kudus: "dan yang lain menanggapi apa yang mereka katakan" (1Kor 14:28). Dalam terjemahan lama memakai kata "dan yang lain-lain mengimbangkan kata-katanya." Hal ini sesuai dengan apa yang dikatakan rasul Paulus dalau surat 1Tesalonika 5:20-21 yaitu: "Janganlah anggap rendah nubuat-nubuat. Ujilah segala sesuatu dan peganglah yang baik." Dalam ayat ini jelas bahwa alamatnya umum, artinya bahwa semua orang Kristen diundang untuk menguji roh. Lenski menjelaskan: "Tentang ujian terhadap kata nubuat (bnd. 1Kor 14:29). Beberapa orang memiliki karunia bagi hal ini. Dasar yang harus dipakai terdapat dalam Roma 12:7, yakni analogi iman." ${ }^{34}$ Terutama dalam konteks pengajaran dan nubuat, bahwa roh harus dibedakan.

Firman Tuhan memberikan banyak tanda yang menolong jemaat untuk membedakan Roh, yaitu pertama, kata "tanda ajaib" dan "nubuat," meskipun dilakukan dalam nama Tuhan Yesus, tetapi tidak boleh dilihat sebagai bukti mutlak bahwa seseorang diutus oleh Allah (Mat 7:21-23; Mrk 13:22-23). Kedua, pengajaran yang sesuai dengan Firman Tuhan menjadi bukti seseorang diutus oleh Allah (Gal 1:6-8; 1Kor 14:37; 2 Kor 11:4, bnd. 2Kor 11:13-14). Ketiga, setiap roh harus diuji apakah dia berasal dari Yesus. Tandanya pengakuan terhadap pribadi Yesus (2Kor 11:4; 1Yoh 2:22-23, 4:1-2). Keempat, seseorang yang sudah lahir baru, dapat berbalik dari

34 "For the idea of testing prophesyings compare I Cor. 14:29. Some had a special gift for this, I Cor. 12:10. The rule to be applied is indicated in Rom. 12:7, the analogy of faith;"' Lenski, Interpretation of First..., 361 
kebenaran dan mengikuti setan (1Tim 4:1-2; ${ }^{35}$ Kol 2:18). ${ }^{36}$ Kelima, hidup seorang nabi atau seorang pengajar harus sesuai dengan pengajaranya (Tit 3:10-11; 1Tim 8:3-5, bnd. 4:2; Mat 7:15-17; 2Ptr 2:1-2). Dan keenam, kalau kita menemukan pengajar atau nabi palsu, tindakan yang diarahkan oleh Paulus jelas sekali. Lebih dulu orang tersebut dinasihati tiga kali, kemudian dia diusir dari jemaat sampai dia bertobat (Rm 16:6,17; 1 Kor $5: 11$; 2Tes 3:6,14; Tit 3:10; 2Tim 3:5, bnd. Mat 18:15-17; Yak 5:18-20; 1Yoh 4:1,6).

\section{Karunia-Karunia Lain}

Masih banyak karunia yang dapat dibahas sebenarnya. Penulis tidak memberi tempat untuk pembahasan yang begitu dalam kepada semuanya, ada beberapa yang masih belum dibahas antara lain: karunia Melayani (Rm 12:7); karunia Menasehati (Rm 12:8); karunia Memimpin (1Kor 12:28); karunia Penginjilan (Ef 4:4); karunia membagikan (Rm 12:8); karunia Menunjukkan Kemurahan (Rm 12:8). Kebanyakan karunia ini adalah karunia yang bersifat praktis, yang sebetulnya kelihatan sederhana. Sering orang tidak mau memperhatikan karunia seperti itu. Jarang ada orang yang minta kepada Tuhan supaya diberikan karunia melayani orang lain (1Kor 12:28; Rm 12:7). Kalau orang meminta karunia memimpin (1Kor 12:28) itu masih dapat dimengerti. Hal ini didasarkan kepada contoh dari Tuhan Yesus sendiri. Dia merelakan diri untuk melayani murid-murid-Nya secara jasmaniah. Melayani orang lain tidak dipuji dan tidak dilihat orang, tetapi Tuhan melihat apa yang dilakukan secara tersembunyi.

Demikian juga karunia membagikan dan menunjukkan kemurahan (Rm 12:8). Karunia ini tidak tergantung kepada kekayaan dan kemiskinan seseorang. Sebetulnya bagi yang suka memberi yang menyenangkan Tuhan dan bukan apa yang diberikan. Sebab "Allah menyukai orang yang memberi dengan sukacita" (2Kor 9:7).

\footnotetext{
35 "Tetapi Roh dengan tegas mengatakan bahwa di waktu-waktu kemudian, ada orang yang akan meninggalkan imannya (avposth, sontai, tinej th/j pi, stewj), lalu mengikuti roh-roh penyesat (terjemahan langsung dari bahasa asli).

36 "Jangan kamu biarkan orang merampas kemenangmu daripadamu" (terjemahan langsung dari bahasa asli). Kata "merampas kemenanganmu" dari kata katabrabeue, tw, artinya mengambil dari seseorang keselamatannya;" Lenski, Interpretation of First..., 361
} 


\section{PENUTUP}

Pada bagian penutup ini menyajikan implikasi teologi Paulus tentang karunia-karunia roh bagi problematika pneumatologis di Gereja masa kini, yang meliputi: problematika pneumatologis yang terjadi di Gereja masa kini, implikasi teologi Paulus tentang karunia-karunia Roh baik secara teologis, ekklesiologis dan missiologis.

\section{Problematika Pneumatologis Di Gereja Masa Kini}

Doktrin tentang Pneumatologi kembali hangat dibicarakan, bukan hanya dimonopoli oleh sekelompok Gereja tertentu, melainkan telah menjadi topik yang hangat dibahas oleh hampir seluruh Gereja di dunia ini, termasuk Gereja-gereja di Indonesia. Menurut Lumintang, di kalangan Gereja-gereja Injili, terdapat banyak pandangan yang bukan hanya berbeda, melainkan bertentangan dengan, bermuara pada dua kutup polarisasi, yakni kutub neo Pentakosta dan kutub non-Pentakosta. Kutub neo-Pentakosta mengklaim, bahwa pemahaman dan pengalaman Pneumatologi mereka adalah: "Chirst centeredness, spirit-emppwered living, emotion finding expression, prayerfulness, joyfullness, every-heart involvement in the worship, every-member ministry in the body of Christ, missionary zeal, small group ministry, attitude toward church structures, communal living, generous giving." 37 Sedangkan kutub non Pentakosta memberikan tanggapan berupa keberatan-keberatan terhadap neo-pentakosta, dengan komentar: "elistism, sectarianism, emotionalism, anti-intelectualism, illuminism, charismania, super-supernaturalism, eudaemonism (happiness), demon obsession, conformism." ${ }^{38}$

Dari sekian banyaknya isu Pneumatologis yang dipermasalahkan, ada dua topik yang sangat menonjol baik yang pro maupun yang kontra yaitu isu baptisan Roh Kudus dan kepenuhan Roh Kudus. Bagi kubu non Pentakosta, isu baptisan Roh Kudus masih menjadi tanda tanya besar, sedangkan bagi kubu Neo Pentakosta dan aliran yang sejenis memiliki penafsiran dan konsep serta praktek yang berbeda berkenaan dengan baptisan Roh Kudus. Gerakan ini telah mempengaruhi banyak Gereja atau orang percaya karena tawaran yang menyentuh perasaan dan pembaharuan rohani disertai dengan adanya penemuan-penemuan baru mengenai kehadiran dan pekerjaan Roh Kudus seperti "jatuh atau rebah dalam roh,

\footnotetext{
${ }^{37}$ Lumintang, Keunikan Thelogia Kristen..., 198

${ }^{38}$ Ibid.
} 
tertawa dalam roh, menangis dalam roh, tidur dalam roh dan lain-lain. Neo Pentakosta telah berusaha merumuskan arti baptisan Roh Kudus berdasarkan pengalaman orang dan mencari ayat-ayat Firman Tuhan untuk meneguhkan dan menjadikannya doktrin. ${ }^{39}$

Motivasi dari semua fenomena dan isu pneumatologis yang sedang hangat dibicarakan menjadi problematika Gereja masa kini adalah: "supaya menjadi orang rohani dengan karunia Roh Kudus, supaya masuk surga (second blessing), supaya hidup diberkati dengan berkelimpahan, supaya mengalami kesembuhan dan supaya luput dari bencana, sakit dan kerugian." 40 Lumintang juga menambahkan bahwa: Dalam penerapan ajaran ini, sebagian besar dari penganut Neo-Pentakosta mengharuskan dengan "memprogramkan" penerimaan Roh Kudus dalam suatu ibadah khusus dengan penumpangan tangan seorang pendeta, menjadi syarat karunia Roh Kudus, karunia bahasa lidah dianggap sebagai senjant untuk mengusir setan, serta dianggap sebagai syarat atau tanda penerimaan Roh Kudus. Oleh sebab itu, dalam upaya menyikapi problematika Pneumatologis di atas, penulis mengajak seluruh pembaca untuk "back to the Bible." 41 Alkitab adalah sumber berotoritas bagi orang percaya memahami pribadi dan karya Roh Kudus.

\section{Implikasi Teologis}

Rasul Paulus menyatakan bahwa kepada setiap anggota jemaat, Allah telah memberikan karunia-karunia Roh Kudus; dimana masingmasing anggota jemaat menerima karunia Roh Kudus yang berbeda-beda, sesuai dengan kehendak-Nya. Dari segala karunia-karunia Roh Kudus yang Paulus sebutkan dalam bagian Firman Tuhan tersebut, di dalamnya tercantum juga karunia-karunia Roh Kudus yang bersifat spektakuler. Meskipun rasul Paulus tidak mengelompokkan semua karunia Roh Kudus yang bersifat spektakuler dalam satu kelompok tersendiri dan menyatakannya sebagai karunia-karunia yang hanya diberikan khusus untuk orang tertentu atau untuk para rasul. Melainkan rasul Paulus menyatakan bahwa semua karunia Roh Kudus tersebut diberikan kepada jemaat dan dibagi-bagikan kepada tiap-tiap anggota jemaat, sesuai dengan kehendak-Nya. Rasul Paulus juga menyatakan bahwa Allah sudah menetapkan beberapa orang dalam jemaat: Pertama sebagai rasul, kedua

\footnotetext{
${ }^{39}$ Ibid., 199

${ }^{40}$ Ibid.

${ }^{41}$ Lumintang, Keunikan Thelogia..., 200
} 
sebagai nabi, ketiga sebagai pengajar. Selanjutnya mereka yang mendapat karunia untuk mengadakan mujizat, untuk menyembuhkan, untuk melayani, untuk memimpin, dan untuk berkata-kata dalam bahasa roh.

Rasul Paulus menjelaskan bahwa nubuat akan berakhir, bahasa roh akan berhenti dan pengetahuan akan lenyap. Karena pengetahuan kita tidak lengkap dan nubuat kita tidak sempurna. Tetapi maksud Paulus mengungkapkan hal tersebut, sebenarnya bukan untuk menyatakan bahwa karunia-karunia tersebut akan berakhir pada waktu berakhirnya zaman para rasul, tetapi untuk menunjukkan ketidaksempurnaannya karunia-karunia tersebut. ${ }^{42}$

Menurut Calvin: It begins, indeed, at death, for then we put off, along with the body, many infirmities; but it will not be completely manifested until the day of judgment, as we shall hear presently. ${ }^{43}$ Yang Paulus maksudkan dengan "yang sempurna" adalah berkaitan dengan kedatangan Kristus kedua kali, dimana setiap orang percaya akan melihat Dia muka dengan muka dan mengenal-Nya sebagaimana keadaan-Nya yang sebenarnya. Pada saat itu segala karunia-karunia Roh Kudus akan berakhir dan tidak dibutuhkan lagi. Sebab apa yang menjadi tujuan atau sasaran dari karunia-karunia Roh Kudus, telah menjadi suatu kenyataan dan disempurnakan di dalam persekutuan yang nyata muka dengan muka antara orang percaya atau jemaat dengan Kristus, pada waktu kedatangan-Nya kedua kali. ${ }^{44}$ Dengan demikian secara teologis karunia-karunia Roh Kudus yang Paulus sebutkan tetap berlangsung sampai saat ini.

\section{Implikasi Ekklesiologis}

Alkitab memandang jemaat sebagai suatu badan yang tiap anggotanya penting untuk melaksanakan fungsi jemaat, dan yang mempunyai peranan yang penting demi kepentingan semua. Jika Gereja menyadari hakikat jemaat masa kini dan kewajiban semua orang Kristen untuk menggunakan berbagai karunia, maka jemaat-jemaat yang stagnan dapat dihidupkan kembali sementara setiap anggota berusaha memainkan peranannya dalam menguatkan persekutuan jemaat. ${ }^{45}$ Penggunaan karunia-

\footnotetext{
${ }^{42}$ G.A. Buttrick (ed), The Interpreter's Dictionary of the Bible. Vol. A (Nashville: Abingdon Press, 1978), 189

${ }^{43}$ Johanes Calvin, Calvin's Commentaries, Vol. XX, I \& II-Corinthians (Grand Rapids, Michigan: Baker Book House, 1979), 428

${ }^{44}$ F.E. Gaebelein (Gen.ed), The Expositor's Bible Commentary. Vol. X (Grand Rapids, Michigan: Zondervan, 1982), 269

${ }^{45}$ Bridge \& Phypers, Karunia-Karunia Roh..., 170
} 
karunia Roh untuk menyembuhkan terhadap orang lumpuh mengakibatkan rangkaian persitiwa, yaitu meningkatkan jumlah keanggotaan orang Kristen di Yerusalem menjadi lima ribu orang dan membungkam perlawanan dari para pemimpin Yahudi. Karunia untuk membagi-bagikan dengan murah hati bertepatan dengan kuasa besar yang memungkinkan para rasul bersaksi tentang kebaktian. Penggunaan karunia berkata-kata dengan pengetahuan dalam menghadapi penipuan juga menimbulkan serangkaian peristiwa yang mencapai puncaknya dalam bertambahnya jumlah orang percaya, yang memperoleh berkat dari pelayanan jemaat. ${ }^{46}$

Penggunaan karunia-karunia roh hendaknya juga menghasilkan kesatuan yang lebih mendalam di dalam jemaat dan di antara semua kelompok Kristen. Perjanjian Baru berkali-kali menekankan bahwa inilah salah satu tujuan karunia-karunia Roh, yaitu bahwa orang-orang percaya yang memiliki karunia hendaknya bekerja dan bereaksi bersama-sama seperti halnya berbagai anggota tubuh kita (1Kor 12:12). Apabila anggotanaggota jemaat menyadari bahwa mereka saling bergantung, maka jemaat diikat menjadi kesatuan yang erat dalam persekutuan dan kasih. Apabila jemaat mengerti bahwa karunia mereka yang berbeda-beda mempunyai nilai yang sama di mata Allah, maka dengan lebih bergairah mereka bekerja sama demi kepentingan bersama. Penggunaan karunia-karunia Roh di dalam umat Kristen juga hendaknya membawa banyak orang untuk memasuki pengalaman kebaktian yang lebih mendalam. Dengan demikian jemaat-jemaat yang mengakui karunia-karunia Roh tidak perlu meniadakan bentuk-bentuk liturgi atau doa-doa tertentu yang menjadi kesukaan mereka, agar dapat menggunakan karunia karunia itu. Jemaat dapat menggunakan bentuk-bentuk kebaktian yang sudah ditetapkan maupun bentuk kebaktian yang spontan dan pertemuan mereka dapat diperkaya karenanya. Tetapi pada masa sekarang di Gereja-gereja yang tidak biasa dengan penggunaan karunia-karunia roh di dalam acara kebaktian, asalkan pertemuan semacam itu diadakan secara terbuka dan orang-orang yang menghadirinya tidak membentuk suatu kelompok suci atau menganggap diri mereka berada pada tingkat kerohanian yang lebih tinggi daripada kelompok lain, maka pertemuan itu tidak perlu menimbulkan kerugian. Dengan sendirinya kebaktian rumah tangga seperti itu hendaknya selalu diumumkan sebagai bagian dari program jemaat yang lazim dan dihadiri oleh gembala sidang. ${ }^{47}$

\footnotetext{
${ }^{46}$ Ibid..., 170

${ }^{47}$ Bridge \& Phypers, Karunia-Karunia Roh..., 174
} 


\section{$\underline{\text { Implikasi Misiologis }}$}

Bagaimanapun penggunaan karunia menimbulkan minat terhadap berita Injil dan sangat memperkuat tuntunan-tuntutan Injil. Dalam 1Korintus 2:9-10 menyatakan bahwa "Tetapi seperti ada tertulis: "Apa yang tidak pernah dilihat oleh mata, dan tidak pernah didengar oleh telinga, dan yang tidak pernah timbul di dalam hati manusia: semua yang disediakan Allah untuk mereka yang mengasihi Dia."

Seringkali tantangan yang harus dihadapi adalah ketidakpercayaan yang militan. Seperti halnya di jemaat Korintus, masa kini juga pengikutpengikut Kristus dikelilingi oleh orang-orang bukan Kristen yang dibingungkan oleh perpecahan di antara umat Kristen dan yang tidak terkesan oleh pengakuan mereka bahwa kasih Allah telah dicurahkan di dalam hati mereka ( $\mathrm{Rm}$ 5:5). Di dalam jemaat sendiri terdapat orang-orang yang meniadakan unsur-unsur supranatural dari dalam Injil. Kabar baik dirumuskan sehubungan dengan perbuatan sosial. Persekutuan dengan Allah hanya sekedar ungkapan untuk menyatakan kerukunan hidup di antara manusia. Doa adalah semata-mata pembicaraan tentang kenyataan. Seolah-olah tujuan jemaat ialah supaya tidak kelihatan. ${ }^{15}$

Di banyak bagian belahan dunia dewasa ini penganiayaan besarbesaran secara teroganisir dilancarkan terhadap Gereja. Jumlah orang Kristen yang mati syahid selama abad ke-21 sama besarnya dengan jumlah para syahid yang mati selama konflik dengan kekaisaran Romawi selama tiga ratus tahun. Kekuatan-kekuatan animisme yang dinyatakan secara menonjol dan agama-gama lama yang muncul kembali diwarnai daya pesona duniawi yang sifatnya melawan. Maka pertanyaannya adalah: pada masa yang penuh tuntutan seperti sekarang ini, apakah Allah sedang menanggulangi keadaan dengan menguatkan umat-Nya akan warisan rohani yang mereka miliki? Mungkinkah kebanyakan orang Kristen tidak mempertimbangkan kesediaan Kristus yang adalah kepala Gereja untuk memberikan karunia-karunia Roh kepada orang demi penguatan, pembinaan dan perluasan umat-Nya?

Jika memang demikian halnya, dan munculnya kembali karuniakarunia Roh yang sudah lama diabaikan itu merupakan bagian daripada rencana Allah dan pertimbangan semacam itu, maka jelaslah bahwa karunia-karunia Roh sangat relevan untuk masa kini. Ada keperluan yang mendesak akan adanya Gereja yang dikerahkan untuk memberitakan Injil selagi masih ada waktu dan kesempatan. Ada keperluan yang mendesak

\footnotetext{
${ }^{15}$ Bridge \& Phypers, Karunia-Karunia Roh..., 175
} 
akan adanya kesaksian yang kuat untuk meyakinkan yang bimbang dan membungkam yang bersifat memusuhi. Kelompok-kelompok Kristen harus diikat bersama oleh kasih dan bekerja sama saling mempercayai, Gereja harus menggunakan segala karunia yang telah diberikan Allah kepada jemaat-Nya dengan tertib dan teratur. 